Journal of Qualitative Criminal Justice \& Criminology • 2020 | Volume 8, Issue 4

\title{
Angry Women and
} Empathic Men: How Individuals "Do Gender" in a Criminal Justice Context Through Conformity or Resistance to Gendered Feeling Rules

\section{Shannon Dodd ${ }^{1}$}

${ }^{1}$ University of Queensland

Published on: Aug 01, 2020

DOI: $10.21428 / 88 \mathrm{de} 04 \mathrm{a} 1 . \mathrm{c} 32 \mathrm{f0} 00$

License: Creative Commons Attribution 4.0 International License (CC-BY 4.0). 


\section{ABSTRACT}

Studies on gender differences in public punitiveness show that women generally hold less punitive attitudes toward offenders than men. The reverse is true, however, when it comes to 'back-end' criminal justice processes, like parole, that involve the early release of prisoners. With evidence to suggest that differing emotional responses may help to explain gender gaps like these, this study draws on the concepts of gendered feeling rules and emotion management, together with the notion of gender as a performance, to explore how men and women enact their gendered identity through emotion in a criminal justice context. The findings highlight the salience of emotions like fear, anger, and empathy to gender differences in public support for parole. Further, they show that while both men and women perform gender by conforming to gendered emotion expectations, they also resist traditional emotion norms.

\section{Introduction}

Many criminological studies have explored gender differences in public punitiveness, offering some insight into men's and women's views on issues of crime and punishment. This research, though, has produced mixed findings. Women are often reported as being less supportive than men of punitive crime responses and more supportive of rehabilitative approaches (Applegate, Cullen, \& Fisher, 2002; Mackey, Courtright, \& Packard, 2006; Spiranovic, Roberts, \& Indermaur, 2012). Women also hold stronger beliefs in the redeemability of offenders (O'Sullivan, Holderness, Hong, Bright, \& Kemp, 2017). However, there is also evidence that women, more so than men, believe the sentencing of offenders is too lenient (Kelley \& Braithwaite, 1990; Sprott, 1999) and that prisoners ought not to be released on parole (Dodd, 2018; Haghighi \& Lopez, 1998; O'Hear \& Wheelock, 2015).

While these research findings are indeed worthwhile, less empirical attention has been given to what is arguably the more important issue - why do men and women hold diverging criminal justice attitudes? There is evidence to suggest that differences in men's and women's affective experiences may provide an answer to this question (Gault \& Sabini, 2000; Labor \& Gastardo-Conaco, 2017; Whitehead \& Blakenship, 2000). Research shows, for example, that "gender differences in emotion influence gender differences in policy preferences" (Gault \& Sabini, 2000, p. 495). The affective dimensions of public punitiveness and the gendered nature of emotions are, therefore, an important avenue for research. First, though, one must decide how best to conceptualize the key construct of gender.

Despite being commonly used in research, the term 'gender' remains misunderstood, even today (Valcore \& Pfeffer, 2018). This misunderstanding may be due, in part, to the trend in some criminological theory and research to ignore the efforts of researchers from other disciplines to 
advance our understanding of gender by continuing to conflate gender with sex (Dolliver \& Rocker, 2018; Valcore \& Pfeffer, 2018). Indeed, many criminological studies that explore the gender gap in criminal justice attitudes adopt binarism, or the view that gender is a fixed biological characteristic represented by the categories of 'male' and 'female' (e.g., Applegate et al., 2002; Hurwitz \& Smithey, 1998; Whitehead \& Blankenship, 2000). This approach is widespread in criminological research, with Valcore and Pfeffer's (2018) recent examination of studies published in seven leading criminological journals showing that gender and sex are still often used interchangeably.

A more nuanced view of gender is offered by social constructionists, who distinguish 'sex' as a biological category from 'gender' as a performance that is socially created and determined through interaction (Cops \& Pleysier, 2011; Valcore \& Pfeffer, 2018). West and Zimmerman (1987) and others (Connell, 1995; Messerschmidt, 2013) conceptualize gender as a type of situated social action, or something that is 'done' or 'accomplished' by individuals throughout their lives through everyday social interactions. From this 'doing gender' perspective, gender is a social construct, whereby men and women behave in gendered ways because of prevailing societal conceptions about femininity and masculinity (Miller \& Mullins, 2006); conceptions that vary across time, context and ethnic group, but where the "opportunity to behave as manly men or womanly women is ubiquitous" (Deutsch, 2007, p. 107).

Given calls for criminologists to continue to move beyond normative conceptions (Miller \& CarboneLopez, 2015; Valcore \& Pfeffer, 2018), this study adopts West and Zimmerman's (1987) view of gender as a performance that embodies masculine or feminine ideals. Doing so allows for the diversity of ways in which men and women respond to gendered feeling rules in a specific context to be explored (Jaramillo-Sierra, Allen, \& Kaestle, 2017), as well as the influence of socially constructed gender identities on a person's crime and punishment attitudes (Dolliver \& Rocker, 2018). Thus, conceptualizing gender as a dynamic and social process will allow for new insights to be gained into public punitiveness.

\section{Theoretical frameworks}

In this study, public punitiveness is examined with respect to the release of prisoners on parole, a penal process that has long been the subject of public criticism and opposition (Fitzgerald, Bartels, Freiberg, Cherney, \& Buglar, 2016; Petersilia, 2003). To frame this exploration of the intersection between emotions and men's and women's tolerance for parole, this study draws on Hochschild's (1979, 1983) theory of emotion management. Hochschild (1979) theorized that cultural beliefs about emotion influence individuals to experience and express emotion in ways that conform to feeling and expression rules, that is, rules that stipulate the appropriate emotions for different social contexts. When a person's emotions or expressions of emotion departed from these rules, Hochschild (1979) argued the person would manage their emotions to produce a more appropriate emotional response. 
Feeling and expression rules are "deeply gendered" (Sorial, 2019, p. 137) because they reflect beliefs that certain emotions are more natural or appropriate for one gender or the other (Shields, 2002). Consequently, from a young age, boys and girls are socialized to experience and express emotions differently (Lively, 2019). Although four decades have passed since Hochschild's original writings, some argue that gendered expectations for emotion remain relevant today (de Boise, 2015; JaramilloSierra et al., 2017; Lively, 2019). Men, for example, are expected to display "affective neutrality" (Lively, 2019, p. 73), while women are expected to be caring and nurturing, and to manage 'inappropriate' emotions like anger (Lively, 2019).

Combining Hochschild's $(1979 ; 1983)$ theory with criminological and other research provides an indication of the gendered emotion rules that may apply to a criminal justice context. Criminological studies largely focus on the relationship between punitiveness and feelings of fear, anger, and empathy, generally finding a positive relationship between punitive attitudes and fear of crime (Baker, Falco Metcalfe, Berenblum, Aviv, \& Gertz, 2015; Butter, Hermanns, \& Menger, 2013; Dowler, 2003) and anger (Hartnagel \& Templeton, 2012; Johnson, 2009), and a negative relationship with empathy (Courtright, Mackey, \& Packard, 2005; Unnever \& Cullen, 2009). Since these three emotions appear most salient to public punitiveness, it is these emotions that form the focus of this study. It is necessary, then, to consider what feeling rules may apply in relation to these emotions in a criminal justice context, and how these rules may differ for men and women.

Importantly, though, the emotions displayed by men and women in a criminal justice context may conflict with those permitted in other contexts. Hochschild (1979) acknowledged this possibility by recognizing that the effects of social change can lead to "contradictions between contending sets of feeling rules" (p. 568). Thus, a move from a 'traditional' social context to a criminal justice context may evoke a different set of feeling rules for fear, anger, and empathy, and cause uncertainty about how one 'should' feel with respect to these emotions (McQueen, 2017). Different social contexts may also compel people to show emotions that are "not necessarily congruent with the display rules associated with their gender" (Brescoll, 2016, p. 420).

As a 'powerless' feeling, fear is widely considered a feminine emotion (Fischer, 1995; Sutton, Robinson, \& Farrall, 2011). Conversely, because fear is incompatible with traditional societal expectations for masculinity (Sutton \& Farrall, 2004; Sutton et al., 2011), men are expected to adopt a "fearless façade" (Goodey, 1997, p. 402) and downplay any fears they might experience. Thus, when discussing issues of crime and punishment, it is expected that men and women will mostly conform to cultural feeling rules for fear. Specifically, women are expected to express frequent and intense feelings of fear. Further, women who are mothers of young children may express the highest levels of fear, with research showing that parenthood intensifies feelings of fear for women more so than for men (Simon 
\& Nath, 2004). On the other hand, it is expected that men will mostly downplay their fears of crime, instead expressing fear only for their spouse and/or children (Snedker, 2006).

Cultural expression rules establish anger as a suitable and even expected masculine emotion (Feldman Barrett, 2017; Fischer, 1995), allowing men to express this emotion in violent or aggressive ways (Sorial, 2019). Women, though, may be punished or viewed as unfeminine if they express anger (Feldman Barrett, 2017). There is a growing body of literature, however, showing an increased willingness amongst women to express anger (Hellum \& Oláh, 2018; Jaramillo-Sierra et al., 2017; Simon \& Nath, 2004). If this extends to a criminal justice context, some women may resist gendered feeling rules to express anger. If they do, it is anticipated these women will be mothers, since mothers, more so than fathers or those without children, may experience and display anger (Ross \& Van Willigen, 1996). Criminologists also suggest that women may react more punitively than men when confronted with criminal offenses, particularly when those offenses involve children (Hurwitz \& Smithey, 1998). It is expected, though, that many, if not most, women will continue to conform to normative expectations for anger since there are not yet clearly defined boundaries for feminine anger, leaving this a murky area for women to navigate.

Lastly, empathy is typically associated with femininity (Bandes \& Blumenthal, 2012), with society expecting women to be "nicer than natural" and men "nastier than natural" (Forseth, 2005, p. 444). These stereotypes persist today, with women expected to be "empathy specialists" (Clark, 2007, p. 42). The failure to meet these standards may come with penalties, with negative consequences for women who do not show empathy and for men who do (Clark, 2007). Thus, in a criminal justice context, it is expected that women will mostly present themselves as empathetic. On the other hand, while normative views of masculinity cast men as unemotional, a growing body of literature suggests that men are increasingly embracing new forms of 'caring masculinity' that value qualities of nurturance and care (Elliott, 2016; Galasiński, 2004; Hanna \& Gough, 2016; Jordan, 2018). If this extends to a criminal justice context, some men may be expressive of empathy toward others.

\section{Methods}

This study draws from in-depth telephone interviews with 30 individuals living in Australia that were undertaken over one year between November 2016 and November 2017. Potential interviewees were recruited using an online survey, a link to which was posted on the Call for Participants website, an online platform for finding participants for academic research. Survey links were also shared on Facebook community groups for five areas across Queensland, Australia. Survey respondents answered several questions about their beliefs about redemption, ability to empathize with others, and fear and anger regarding crime. Some demographic information was also gathered. A total of 351 usable surveys were collected. From these, 30 individuals were purposively selected to be interviewed. A four-item 'Belief in Redeemability' scale guided this recruitment due to its ability to predict punitive 
attitudes (Maruna \& King, 2009). Individuals with below and above-average scores on this scale were recruited for participation, to ensure interviewees likely held a range of views about offenders and the possibility of their release on parole. In the final sample, male interviewees had an average score of 3.35 on the "Belief in Redeemability" scale, while female interviewees had an average score of 3 . This indicates that male interviewees held marginally stronger beliefs about redemption for offenders than female interviewees.

Interviewees' gender, age, and state or territory of residence were also taken into consideration during recruitment, to ensure some variety on these demographic factors. Participants were asked to identify their gender as 'male', 'female', or 'other'. An equal number of individuals who identified as men $(n=15)$ and women $(n=15)$ were selected for interviews. Male and female interviewees were not matched on other demographic characteristics; however, an effort was made to ensure that participants within each group represented a variety of age ranges and places of residence. Because only one person from the 351 usable surveys identified their gender as 'other', it was not possible to meaningfully explore the views of individuals from this category.

Interviewees were provided a definition of parole, an explanation of how parole works, and a onepage vignette describing a hypothetical offender who was seeking release on parole. The vignette was designed to include the most important factors required for parole decision-making (Alexander \& Becker, 1978), including information on the offense type and sentence, the offense circumstances, the offender's institutional behavior, and a risk assessment. The vignette described a 26 -year-old man who had served half of a four-year sentence for supplying "Ice" to two 16-year-old girls. The offender had a history of homelessness and prior offenses.

The decision to use a vignette to structure interviews was made for several reasons. First, the combination of a vignette with qualitative interviews is likely to provide the most comprehensive information on punitive public attitudes (Adriaenssen \& Aertsen, 2015). Second, it has been suggested that research participants may be less likely to engage in impression management techniques when responding to a vignette than when answering more direct questions (Alexander \& Becker, 1978). Research also suggests that vignettes elicit a more powerful emotional response from research participants (Kogut, 2011), with Kutateladze and Crossman (2009) arguing that "crime vignettes provide more vivid pictures than abstract questions, and therefore, the former might have more power to arouse anger against criminals and fear for oneself, than the latter" (p. 15).

Interviews followed an in-depth, semi-structured interview design and lasted, on average, 45 minutes. The interview guide included some general questions about the early release of prisoners and whether offenders are capable of redemption. Interviewees were also asked more specific questions, including whether they felt angered knowing that offenders may not serve their entire sentence in prison and what feelings they had concerning the high-profile cases of parole 'failure' in Australia (or elsewhere). 
Through these questions, information regarding the emotions experienced by interviewees in the context of discussing parole, and the effect of those emotions on their parole decision and their views on parole, more broadly, was collected. Over the course of conducting the interviews, additional questions were added to the interview guide to explore further themes that had emerged from a preliminary coding of earlier interviews. For example, following comments by a female interviewee about her perceptions of how men might view parole, all subsequent interviewees were asked whether they believed their views were similar or dissimilar to the views of members of the same and opposite sex. In addition, it became apparent during some early interviews that a person's parental status was influential to both their emotions and attitudes toward parole and so all subsequent interviewees were asked whether they were a parent.

All interviews were audio-recorded for later transcription. To analyze the data, a thematic analysis of the transcripts was undertaken using the theoretical framework and Hochschild's $(1979,1983)$ theory as a guide. A theoretical, or abductive (Dey, 2004), approach to coding was taken whereby the data were examined to identify instances where participants spoke of the emotions they felt, either generally or as part of their views on the release of prisoners on parole. This coding identified interviewees' expressions of fear, anger, and/or empathy (together with other emotions). Instances were also coded where participants appeared to be managing their emotions by downplaying or attempting to elicit certain feelings. Comparing the themes for male and female interviewees, the gendered patterns of emotion and emotion management were then examined and recorded.

\section{Findings}

\section{Overview of parole decisions}

At the beginning of each interview, interviewees were asked to act as a mock parole board member and make a parole decision for the offender. Because previous research indicates people are less punitive when asked to make a parole decision for a specific offender than when asked to respond to global-style questions about their support for parole (Cumberland \& Zamble, 1992), it was anticipated that many participants would choose to grant parole. Despite this, given previous research (Dodd, 2018), it was still anticipated that a larger proportion of men than women would grant parole. Consistent with these expectations, all but one male interviewee (93\%; $n=14$ ) said they would grant parole, while the remaining man $(7 \% ; n=1)$ was undecided as to his parole decision. Among female interviewees, 80 percent $(n=12)$ said they would grant parole, while the remaining 20 percent $(n=3)$ said they would refuse parole.

\section{Findings of thematic analysis}

The following presentation of findings is structured through a thematic discussion of men's and women's expressions of fear of crime, then anger and empathy in a hypothetical parole context. If, as 
Hochschild's $(1979,1983)$ theory of emotion management suggests, men and women are guided by cultural emotion norms when acting as mock parole board members, we would expect men's and women's affective experiences and behavior to coincide with the dominant cultural beliefs about gender and emotion. As the following analysis demonstrates, while feelings of fear, anger, and empathy are important to how people view the release of prisoners on parole, how men and women express these emotions does not always align with traditional ideas about masculinity and femininity. Instead, men and women were observed to conform at times and at others to resist gendered emotion rules as they enact their gendered identity and navigate the boundaries of performing their gender in a criminal justice context.

\section{Fear of crime: A mostly feminine emotion}

During interviews, men and women tended to conform to normative cultural beliefs about fear, with most women openly describing their fears of crime, and most men distancing themselves from this emotion. Amongst female interviewees, feelings of fear were commonly described as relating both to their personal fears about crime (namely, the fear they felt for themselves), as well as altruistic fears of crime (the fear they felt for others, like children and other loved ones). In describing their personal fears of crime, five female interviewees said that being a woman made them feel physically vulnerable to victimization. Embodying a maternal role, four female interviewees also expressed altruistic fears about crime with respect to their children or parents (Snedker, 2006).

Apart from feeling physically vulnerable to victimization, three women pointed to a fear of burglary as being responsible for their fears of crime. For these women, the fear of being burgled was linked to their concerns about contemporaneous offending (Warr, 1984), that is, the possibility that a burglary could escalate or be accompanied by acts of physical or sexual violence against household occupants. As one woman described, "it's always on my mind as well that not only might someone rob the house, but they could be more violent when they do so" (PA23, Female, 45-54, granted parole). These findings are similar to those of Gilchrist and colleagues (1998), where women also often spoke of a specific fear of burglary and of the acts of violence that might occur alongside that offense.

Perhaps because these women's expressions of fear were consistent with prevailing conceptions of femininity as being linked to vulnerability (Hollander, 2001), most women did not downplay or distance themselves from their fear. Amongst these women, experiencing and expressing fears about crime was represented as an expected and normal part of womanhood. However, one interviewee, a young female lawyer, was clearly conflicted about the emotions she 'should' feel or express, due to the contradictory emotion rules associated with her competing social roles (Thoits, 1990). As a woman, feelings of fear were clearly appropriate for her, but as a lawyer and indeed a mock parole board member, fear could potentially undermine her status as a legal professional. She was, therefore, caught in an 'emotional double bind' (Shields, 2005), a situation where competing emotion rules make 
it difficult to conform to the appropriate emotion standards. Such binds are common amongst career women, particularly those working in traditionally male-dominated occupations, as they may be "forced to choose between femininity and an image of professionalism" (Rabe-Hemp, 2009, p. 114).

To maintain her professional standing and present as an 'appropriate' parole decision-maker, there was evidence that this woman downplayed her feelings of fear to evoke instead what she viewed as a more appropriate and feminine emotion for the situation- empathy:

Participant: ... while I guess I come from a relatively privileged background, I do get worried about things like break-ins, that sort of thing, so if I'm home alone for example I do get pretty scared generally because I know what happens.

Interviewer: And so ... if you feel fairly scared of crime, does that influence how you feel about parole and this idea of letting people out of prison earlier?

Participant: Not really, to be honest. I guess I have thought about it and I'm still empathetic regardless because I guess the world's a pretty awful place sometimes. (PA9, Female, 25-34, granted parole)

The conflict experienced by this woman about expressing her feelings of fear is consistent with the findings of Lively (2000), who reported that outward displays of emotions, like fear, by (predominantly female) paralegals were considered unprofessional. Thus, like the female paralegals in Lively's (2000) study, this woman attempted to maintain an outward display of professionalism by restraining the 'inappropriate' fear she felt to instead present feelings of empathy which, in the context of parole where processes are said to "manifest concern for offender welfare" (Vîlcică, 2018, p. 1358), were the more appropriate emotion.

Men also mostly conformed to gendered feeling rules about fear by, in their case, denying being fearful of crime. Most men attributed their lack of fear to one of two related factors - firstly, feeling safe in their community (five men) and secondly, perceiving their risk of victimization to be low (four men). However, while cultural feeling rules suggest that fear is not an 'appropriate' masculine emotion (Fischer, 1995), fatherly expressions of fear have perhaps become more socially acceptable due to the emerging view of 'New Fatherhood' that allows fathers to embrace a more nurturing role (Shields, 2002). The renegotiation of gendered fear norms for fathers was apparent in interviews with two men, who were both fathers to young children. Although these men were careful to downplay their personal fear of crime, they did express fear for their children. As one explained, "I've got a one-yearold and four-year-old daughters, and yes, my fear is probably more for them than it is for me" (PA13, Male, 35-44, granted parole). 
While both men and women expressed fears about crime for their children, it was apparent that the interplay between parenthood and emotions differed for men and women. Like the findings of earlier studies (Ross \& Van Willigen, 1996; Simon \& Nath, 2006), the analysis indicated that, for at least some women, parenthood resulted in intensified feelings of fear on behalf of their children and anger toward offenders, while for men, being a father resulted in a quite different emotion. Two female interviewees expressed strong fears for the safety of their children. Both decided to deny parole to the offender in the case study. For these women, denying parole served a dual purpose - to mitigate their fears about the dangers posed to their children and to ensure the offender was appropriately punished for his wrongdoing. Thus, feelings of fear and anger were closely intertwined for these women, confirming that these emotions can be experienced simultaneously, at least for women (Shields, 2002):

I mean it's terrifying that people are making those decisions that might impact my children. My son is starting high school, so he might be the one walking out of the high school and someone's there [selling drugs] and they want to be cool. It shouldn't be something that we have to worry about, that someone who has offended and been caught, now we have to worry about them too because they've been released early. It shouldn't be-if they've been caught, they need to be punished to the absolute strength of the sentence-be it as weak as it is-so that isn't a worry we have as well. (PA11, Female, 35-44, denied parole)

Conversely, five male interviewees described how fatherhood had made them more empathic. As one man explained: "I've probably become a fair bit more empathetic, I guess, since we've had kids" (PA13, Male, 35-44, granted parole). Indeed, for many men, the ability to empathize with the offender was an important factor leading them, as a mock parole board member, to grant parole. This is discussed further below.

\section{Anger: A masculine (but also feminine) emotion}

Consistent with gendered feeling rules and normative views of masculinity, feelings of anger were common amongst many men, with about half of all male interviewees expressing anger about parole or the criminal justice system more broadly. In most instances, the anger described by men was closely connected to their perception that some injustice had occurred (Sorial, 2019). Some men explained that they were angered by what they viewed as the lenient treatment of offenders, as well as perceived increases in crime:

It's gotten to the point now where, you know, if you don't lock your house up at night, you run the risk of somebody breaking into your house and assaulting you ... It makes me angry that we've got to basically imprison ourselves in our own homes against the outside world because it seems that crime is forever increasing, not decreasing. (PA18, Male, 65-74, granted parole) 
This man, like the women discussed earlier, expressed concerns over both the possibility of being burglarized and of the acts of violence that could accompany that offense. However, rather than describing feelings of fear, as the women did, he instead expressed the more masculine responsethat of anger.

With respect to parole, some men expressed feelings of anger that stemmed from their belief that releasing offenders 'early' would lessen the deterrent effect of imprisonment. For others, feelings of anger were linked to specific cases where an offender had been paroled when, in their view, the offender clearly posed a risk to the safety of the community:

... we've heard so many cases where people have been killed because someone's been let out on [parole]. I mean, it was beyond question that [Adrian Bayley] 1 might be a threat to society. They let him out and he goes out and kills and rapes another woman. So, there are cases where I think [parole] should be absolutely denied, and not because they think he's going to scoot off, but he could be a threat to society ... [S] that's probably the anger I feel. (PA26, Male, 55-64, granted parole)

When discussing cases of parole 'failure', two male interviewees were careful to distinguish between anger and frustration, an emotion related to anger but milder in intensity (Aldrich \& Tenenbaum, 2006; Krehbiel \& Cropanzano, 2000). When asked whether he was angered by cases like the one involving Bayley, one man clarified, “Anger, probably no. Frustrated, yes. I'm frustrated that that's something that could happen" (PA2, Male, 25-34, granted parole). Frustration, a stereotypically masculine emotion (Brody, 1996), is said to result from a situation where a person feels an unfavorable outcome has occurred due to an inherently unfair process (Krehbiel \& Cropanzano, 2000). It is possible that these two men experienced feelings of frustration due to what they perceived as an inadequate parole system that had allowed dangerous offenders to return to the community. Alternatively, these men may have considered that anger was too intense an emotion to express when acting as mock parole board members since anger is often considered irrational and disruptive in a legal context (Sorial, 2016). Thus, they may have managed their anger to describe feelings of frustration instead, since this "mitigated form of anger" (Aldrich \& Tenenbaum, 2006, p. 783) may have been more appropriate, in their view, for them to describe in this context.

Not all men, though, conformed to feeling rules for anger, with some distancing themselves from this emotion. This was particularly apparent amongst two older men. One interviewee explained that he did not focus on crime-related issues from an "anger perspective" and that he was not one to ever dwell on this emotion (PA27, Male, 55-64, granted). The second man said that although he might have been angered by crime-related issues when he was younger, this emotion was now "pointless" and of no use to him (PA22, Male, 55-64, granted parole). 
The notion that anger is an emotion befitting men, but not women, is perhaps the most enduring of all Western cultural feeling rules (Shields, 2002). Indeed, many emotions scholars continue to argue that women who express anger are likely to be viewed as emotional deviants (Brescoll, 2016; Feldman Barrett, 2017; Sorial, 2019). Although early research indicated that, compared to men, women were less likely to express anger outwardly (Frost \& Averill, 1982; Kopper \& Epperson, 1991), more recent studies suggest women are becoming increasingly expressive of their anger (Jaramillo-Sierra et al., 2017; Ross \& Van Willigen, 1996; Simon \& Nath, 2004). Consistent with this literature, but contrary to the gendered feeling rules observed in other social contexts, about half of all female interviewees openly expressed feelings of anger when discussing parole and the criminal justice system. Like men, several women expressed anger regarding incidents of parole failure. As one woman, a mother, explained, she felt "angry and disappointed. You're angry at the system, and I guess you're angry at [the offender] as well" (PA5, Female, 35-44, denied parole).

As was the case with fear, feelings of anger were most strongly expressed by three mothers. These women appeared to feel entitled to their anger, as their emotional reaction was justified or deserved by those who commit criminal offenses (Lacey \& Pickard, 2015). One woman, a mother of both a son and daughter, said she felt very angry about crime-related issues. When asked what caused this anger, she explained, "probably because of the drugs and the violence at the moment is quite high and that makes me very cross I guess because I just think there's no need for it" (PA8, Female, 35-44, denied parole). Another woman, a mother of two young boys, expressed anger about the release of offenders on parole, which she felt undermined the work of police officers in detaining offenders:

I get very cross that offenders are caught by the police, who put themselves in danger to get these people out of the community, and then they go back into the community through the parole system and they reoffend immediately ... [I]f they are letting people out early when they are these massive risks of violence, how could you possibly think this is ok? (PAll, Female, 35-44, denied parole)

While both of these women expressed feelings related to anger, they did so using what one might describe as maternal or subdued language - i.e., feeling 'cross'. While these women may have viewed feelings of anger as too intense for a mock parole board member, it is possible that they felt it would be unseemly for a woman to speak of an emotion as intense and masculine as anger and therefore negotiated their expression of this feeling. They may have also downplayed the intensity of their anger to avoid any suggestion that they were not in control of their emotions (Galasiński, 2004).

Despite this, the willingness of these women to express anger adds support to the argument that women may be increasingly willing to resist gendered feeling rules regarding anger. Alternatively, it could suggest there may be unique feeling rules that allow women, as legitimately as men, to express anger in a criminal justice context rather than merely feeling fearful or sad. Indeed, the 
appropriateness of maternal anger in this context was described by many interviewees. Three men, for example, expressed the view that women, and mothers in particular, would be especially angered by the actions of the offender seeking parole or any other offender whose actions had negatively impacted children. One man went so far to say that if he were the offender, he would prefer that no women sat on his parole board because female parole board members, if they were mothers, would be influenced by maternal feelings towards the victims:

Traditionally women are very protective of their children, their offspring. And, you know, you can say that this person is basing their decision on all the facts in front of them but, if that woman had a kid, in the back of her mind, in her subconscious she's going to be considering that those kids are her kids. (PA21, Male, 55-64, granted parole)

However, despite being a father himself, this interviewee felt that, unlike mothers, fathers would not be similarly influenced by their experiences of parenthood. It was not just male interviewees, though, who expected more intense anger from mothers in a criminal justice context, with three women echoing this view. One woman, who was not a mother herself, expressed the opinion that many women would prefer to "lock everyone up and leave them there" (PA16, Female, 35-44, granted parole). While she supported the idea of parole herself, she felt other women would not, particularly if they were mothers:

In this day and age, a lot of women seem to be a lot harder when it comes to-I don't know, maybe because a lot of women have families, and I personally don't. So, a lot of women have children and stuff like that, and obviously they don't want their children around [drugs]. Maybe that could be the difference; they've got more to protect. (PA16, Female, 35-44, granted parole)

The analysis also showed, however, that five women conformed to feeling rules for anger, perhaps because they were unsure of the boundaries of when they have permission (or not) to express anger in a criminal justice context. There were some indications that female interviewees were unsure whether anger is befitting of all women, or just mothers, or how angry women are 'allowed' to feel. While a few women appeared comfortable describing their anger (albeit sometimes using muted language), many others showed uncertainty as to the appropriate emotional response. One woman, a mother and grandmother, appeared conflicted as to whether to express feelings of anger or a more gender appropriate emotion. While she initially described feelings of anger, she then attempted to distance herself from those feelings to instead emphasize the more traditionally feminine emotion of sadness:

Participant: A lot of [my anger] is to do with the kids getting hurt, there seems to be a really bad increase in it all. So, it's really sad. It makes me sad more than angry, you know? It does make you quite, you know, when it shows up, I don't believe that anyone's life should be taken, whether they're a kid or an adult. But yes, it would make it very difficult for me to sit on a parole board for 
a murderer, I wouldn't want that choice really, to tell you the truth ... Especially if they went out and re-offended, that would really top the cake.

Interviewer: It would be difficult, yes. And so, you indicated, yes I do feel angry, but it's more sadness for you, is it?

Participant: Yes. It is anger because it's a waste. (PA20, Female, 35-44, granted parole)

Another woman, also a mother, expressed her anger about the offender and his behavior of selling drugs to teenage girls. She explained how these feelings were influential to her decision to deny parole for the offender because the victim "could be my sixteen-year-old daughter one day" (PA8, Female, 3544, denied parole). However, when asked if she felt angry about offenders being released on parole, she denied that she had experienced feelings of anger or that such feelings were influential to her views, saying “It doesn't really anger me, but-it doesn't anger me, I just think that they're not really learning a lesson perhaps if they're [released early]" (PA8, Female, 35-44, denied parole). While this woman appears aware that maternal anger may be an appropriate emotional response, her uncertainty about the boundaries of anger in this context meant that she tried to distance herself from those emotions.

\section{Empathy: Compassionate women and caring fathers}

Of all the emotions described by men and women in the context of discussing parole, it was feelings of empathy that were the most frequently and strongly expressed by interviewees. Like anger, interviewees' expressions of empathy were not, however, always in the expected fashion, with many men and women resisting normative ideas about masculinity and femininity through their departure from gendered emotion norms.

Most male interviewees $(n=9)$ openly expressed empathy toward the offender, demonstrating their willingness to understand or take the offender's perspective. By doing so, they adopted a care-based approach to moral reasoning that is usually thought to be characteristic of women, and not men (Gilligan, 1982). Because the offender's behavior was, in the view of many men, to be outside of the offender's control, what might have otherwise led to feelings of anger were instead replaced with feelings of empathy and understanding (Weiner et al., 1997). For eight of these men, feelings of empathy toward the offender were accompanied by a focus on the mitigating factors of the offender's case and history. They commonly stated they could understand why the offender had resorted to selling drugs, with many believing this may have been his only choice to secure an income.

By taking the offender's perspective, six male interviewees displayed more empathy for the offender than they did for his victims. Male interviewees tended to attribute at least some responsibility for the crime to the victims, with one reasoning that "the girls weren't forced into it. They were part of the 
crime. He just happened to be the person that was supplying them [with drugs]" (PA26, Male, 55-64, granted parole). Empathy for the offender even led one male interviewee to express negative feelings toward the victims, demonstrating what Vitaglione and Barnett (2003) refer to as 'empathic anger', that is, empathy toward one person that results in feelings of anger toward another: "these little 'angels' went up to this guy and bought drugs off him. So, these two girls that bought the drugs, didn't buy it on the spur of the moment ... they knew what they were doing" (PA21, Male, 55-64, granted parole).

While it is possible that male interviewees were more easily able to identify with the offender because he was also a man, previous research has shown that, unlike women, men's level of punitiveness toward offenders and support for rehabilitation does not vary depending on the gender of the offender (Applegate et al., 2002). It is possible, therefore, that men might display comparable levels of empathy and understanding toward female offenders also. It may be the case, though, that this empathy or understanding is reserved for victims who adhere to stereotypically feminine behavior, while those who engage in inappropriate or unfeminine behavior may be viewed unfavorably and complicit in their own victimization (Garland, Policastro, Richards, \& Miller, 2017).

Women, on the other hand, less often attributed blame to the victims. This is consistent with the broader literature on victim blaming, which shows that women are less likely to engage in victim blaming than men, across a variety of contexts (e.g., Bryant \& Spencer, 2003; Thornberg \& Knutsen, 2011). While a few took the view that the two 16-year-old victims should have known better, many $(n=7)$ women viewed the victims as vulnerable and too young to understand the ramifications of their choices. For some women, the age and gender of the victims made the offense particularly serious. One woman, who chose to deny parole to the offender, admitted she would have viewed the case differently had the victims been different: "I think I would feel differently if [the offender] sold [drugs] to a 35-year-old, and not a 16-year-old. But when you're selling it to kids, I hate that" (PA8, Female, 35-44, denied parole). The finding that women tended to view the offense as more serious because it involved minors adds support to the argument that women will react more punitively toward offenders whose crimes involve children (Hurwitz \& Smithey, 1998).

Many men spoke of personal experiences that allowed them to empathize with and better understand the offender's perspective. Adding support for the argument that fathers are embracing more caring forms of masculinity (Jordan, 2018; Scheibling, 2018; Shields, 2002), five men expressed how becoming a father had increased their empathy for others. As one man explained, being the father of a young son had caused him to look for explanations for poor behavior, rather than to automatically react angrily or punitively. Because of the level of understanding he sought as to why people behave in certain ways, he could see the benefit of granting parole to the offender. 
Two men spoke of having been imprisoned themselves and a few others described having friends or family members who had previously or were currently serving a prison sentence; factors shown to result in stronger beliefs in the ability of offenders to change and redeem themselves (O'Sullivan et al., 2016) and more favorable views on prisoner reentry (Rade, Desmarais, \& Burnett, 2018). One man explained he had been homeless at one time, while another described how working with people with hearing disabilities made him more empathetic to the difficult circumstances faced by others. Further, for other men, the idea that 'everybody makes mistakes' was important to their support for prisoner reentry and openness to allowing the offender to be released on parole.

For all of the men interviewed, there was underlying support for the idea that the offender could, and had, rehabilitated. Further, nine men confirmed that their feelings of empathy toward the offender had, in some way, influenced their parole decision. In doing so, they demonstrated their seeming lack of concern that their decision might be undermined or deemed irrational due to the commonly held belief that empathy should not impair a person's ability to make difficult decisions (Bar-on \& Parker, 2000 , as cited in Brescoll, 2016). As one man explained, being provided information about the offender's background "absolutely does change my thinking ... I definitely take that sort of stuff into consideration" (PA13, Male, 35-44, granted parole). Another admitted that he would have viewed the case quite differently, and perhaps made a different parole decision, had the offender's circumstances been different: "I would have less sympathy because I'd have harder trouble understanding, saying I understand why you did this" (PA14, Male, 35-44, granted parole).

Like the feminine expressions of anger, these findings show that men feel free to express emotions in a criminal justice context that are not typically associated with their gender in other contexts. As was also the case for feminine anger, there was some acknowledgment from several interviewees (one man and three women) that men might be more compassionate than women in their attitudes toward offenders. As one woman described:

You would just think that women automatically would be more empathetic, but you also wonder, or I wonder, if men would be more empathetic towards [the offender] because they've all, or some of them have, had hardships in their lives and done stupid things, and whether they'd view [the offending] as a stupid thing, rather than an automatically criminal thing. (PA15, Female, 4554 , granted parole)

Not all interviewees, though, felt that men would be more empathic than women. One female interviewee felt that men would not give due consideration to the offender's background when coming to a parole decision, saying: "I don't think that [men] would look at it in too much depth, and I think they would not, they probably wouldn't think about the circumstances that offenders have been through" (PA24, Female, 45-54, granted parole). 
While feelings of empathy toward the offender were clearly influential to most male interviewees, the same could not be said for female interviewees. Although the same number of women as men expressed feelings of compassion and understanding for the offender, these feelings were not as salient to women's parole decisions. Nine women expressed their understanding of why the offender had resorted to illegal acts to gain some income. For example, as one woman reasoned, "The homelessness to me is something that I looked at and went, oh right, okay, well that kind of goes hand in hand with what's going on with this person" (PA24, Female, 45-54, granted parole). However, when asked how influential their feelings of empathy were to their parole decision, only two women said that their compassion for the offender had influenced them to grant parole. Conversely, six women denied that their decision was, or would ever be, influenced by their affective reaction to the offender and his circumstances. One woman explained that while knowing information about the offender and his history of homelessness made the decision to deny parole more difficult, she was not the type of person who would allow her feelings of empathy to excuse criminal behavior. Another was careful to emphasize that feelings of empathy would "never" have any bearing on her decision, adding that she found "empathy a really hard thing when it comes to certain crimes" (PA11, Female, 35-44, denied parole). She appeared wary, however, of being perceived as uncaring, going on to explain: “I'm an extremely kind person" (PA11, Female, 35-44, denied parole).

Women managed their feelings of empathy toward the offender using several different techniques, oftentimes simultaneously. Some redirected the empathy they had initially described for the offender to the victims. One woman explained that "anybody who is homeless really gets to my heartstrings" (PA17, Female, 45-54, granted parole). However, when asked how influential her feelings of empathy toward the offender was to her parole decision, she denied that it was a relevant factor, saying that her primary concern lay instead with the children who were exposed to drugs because of the offender's actions:

I didn't look at the homeless issue as the big issue. I thought more about the children or the people that were getting - the children, I mean the kids who were getting a hold of the drugs that he was actually pushing - how it's affecting them. (PA17, Female, 45-54, granted parole)

The second technique used by women to manage their empathy toward the offender was to deny that they had any emotional investment in the case and instead emphasize their detachment. One woman, who had also attempted to redirect her empathy from the offender to the victims, reinforced that she had maintained an appropriate social distance from the case and had made her parole decision based on relevant, emotionless factors only:

... it's not a tender-hearted woman that's saying [to grant parole]. I'm trying to look at it based on facts, rather than emotional ties. I've got no one in my family that has done time or anything like that. It's not something that is close to my heart. (PA17, Female, 45-54, granted parole) 
A second woman took a similar approach, describing how she was able to detach from her feelings of empathy for the offender, as she would in her job as a teacher. She felt it was more important that rule breakers be appropriately punished: "I can detach myself in that, yes, I can display empathy but I can also say, oh well, this is, unfortunately, the rules" (PA5, Female, 35-44, denied parole). Further, some women distanced themselves from their empathy by reasoning that the offender should be held accountable for his actions, despite the hardships he had faced.

By acknowledging their empathy toward the offender but emphasizing that these feelings did not alter their views about punishment, these women attempted to show that they had risen above or put aside their emotions (Lutz, 1996). Further, these techniques allow women to display the expected feminine qualities of being caring and empathic, whilst also meeting expectations for parole board members to maintain an appropriate social distance. By appearing to set aside their empathy toward the offender, women could avoid being labeled as 'soft-hearted' women who had (wrongly) allowed their emotions to influence their parole decision. However, they could also avoid the consequences that can come with being labeled emotionally inexpressive, since women who appear to be lacking in emotion have failed to fulfill their "warm, communal role as women" (Brescoll, 2016, p. 415). Thus, unlike male interviewees, women had to navigate contradictory societal expectations that they be compassionate toward offenders, but at the same time, did not allow those feelings to influence their ability to make an objective decision (Brescoll, 2016; Shields, 2013).

\section{Limitations}

This study had some limitations. To begin, interviewees were made aware through consent procedures that this study was interested in gender differences in public attitudes toward parole. It is possible that knowing this study's focus on gender may have primed some participants to present themselves in a stereotypically gendered manner (Ryan, David, \& Reynolds, 2004). However, because participants' construction of their gender through social interaction was crucial to this study, it was decided not to attempt to deceive interviewees.

Further, because gender is pervasive in all aspects of social life, it is inevitable that qualitative interviewing will involve aspects of gender performance and impression management (Broom, Hand, \& Tovey, 2009). Thus, it is likely that the performance of the researcher's own gender (as a woman) may have influenced how interviewees presented themselves and framed their responses to questions. Research shows, for example, that men use the interviewer's gender "as a cue to gauge the interviewer's orientations and opinions" and to develop "their responses within that gendered context" (Williams \& Heikes, 1993, p. 288). It is possible, therefore, that male interviewees may have answered questions in a certain way (or avoided saying certain things) because of the researcher's own gendered performance (Broom et al., 2009). In other ways, though, this may have been advantageous for data collection, with research indicating that female interviewers may have more success in 
encouraging male interviewees to speak about topics they might otherwise avoid, like emotion (Manderson, Bennett, \& Andajani-Sutjahjo, 2006).

The use of telephone interviews to collect qualitative data can also be contentious, with some pointing to the inability of researchers to observe the social cues displayed by interviewees as one reason to avoid this method (Opdenakker, 2006). This may present a particular difficulty in research focusing on the emotions displayed and managed by interviewees. Despite this, telephone interviews can result in the same amount and quality of data gathered through face-to-face interviews (Sturges \& Hanrahan, 2004) and also often benefit from an increased willingness of interviewees to speak freely and to disclose sensitive information (Novick, 2008). Furthermore, despite a reduction in some social cues, other important cues for interpretation remain, including the interviewee's voice and intonation (Opdenakker, 2006). With the use of active listening practices and a keen awareness of how interviewees are responding to questions, the use of telephone interviews can result in a participantcentered approach that produces rich qualitative data (Trier-Bieniek, 2012).

Finally, the type of crime described in the vignette and the inclusion of young, female victims may have had some influence on men's and women's emotional responses to the case. For this reason, and because previous research suggests that members of the public are more likely to grant parole for drug offenders than other offender types, including those convicted of arson or armed robbery (Estrada-Reynolds et al., 2016), future research should explore men's and women's affective reactions toward different offender types, including those convicted of violent, sexual and property offenses. Their affective responses and views on parole for both male and female offenders should also be explored, given research showing that women, unlike men, may be more supportive of rehabilitation and less punitive toward female than male offenders (Applegate et al., 2002).

\section{Discussion}

Increasingly, researchers have recognized the need to better understand gendered criminal justice attitudes, in part because of the growing involvement of women in political, legal, criminal justice, and policymaking roles (Applegate et al., 2002; Hupfeld, 2009; Kutateladze \& Crossman, 2009). This includes women's greater participation as parole board members. Some researchers suggest that shifts toward increased female involvement in criminal justice decision-making may significantly affect how offenders are punished (Kutateladze \& Crossman, 2009). Applegate et al. (2002), for example, argue that women's participation in correctional and crime policymaking could have a more "humanizing influence" (p. 98). Others, though, recognize the difficulty in predicting whether more female involvement will result in a greater emphasis on offender treatment or the harsher punishment of offenders, given the largely conflicting research findings (Kutateladze \& Crossman, 2009). Indeed, after finding that women were just as punitive as men, at least toward violent offenders, Hupfeld (2009, p. 99) commented that "one might be less optimistic about the potential humanizing effects" of 
women's involvement in correctional policymaking. Whatever the case may be, it is important to gather reliable information regarding women's views on issues like parole, and how those views differ from men's, to enable us to understand better "what a 'female voice' on criminal justice might mean" (Kelley \& Braithwaite, 1990, p. 551). This study provides a step in that direction.

Alongside gender, this study also provides a better understanding of the affective dimensions of public views on parole. Although matters of crime and punishment are inextricably intertwined with emotions like fear, anger, and disgust, criminological researchers have largely failed to appreciate or capture the feelings that might underlie public punitiveness (Indermaur \& Hough, 2002; Loader, 2011). Thus, this study used Hochschild's $(1979,1983)$ theory of emotion management as a theoretical frame through which to better understand the interplay between gender, emotion, and emotion management when exploring men's and women's affective expressions and behavior as mock parole board members. The analysis explored how men and women 'do gender' through their conformity or resistance to gendered feeling rules. It also explored the possibility that a criminal justice context might impose different sets of feelings rules from those observed in other contexts, whereby men and women may be freer to express emotion in ways that do not necessarily conform with the feeling rules associated with their gender.

The findings revealed that feelings of fear, anger, and empathy are important emotions not only in the context of people's attitudes toward offenders more broadly but also with respect to their views regarding the release of prisoners on parole. Both men and women spoke of these three emotions, demonstrating the affective dimensions underlying their attitudes toward parole. Many women, for example, appeared influenced by feelings of fear and/or anger and, consequently, displayed some wariness of releasing offenders from prison early. On the other hand, men appeared most moved by feelings of empathy toward the offender, which appeared to be instrumental in leading them to view parole favorably.

The findings also showed that while some men and women conformed to prevailing gendered feeling rules, others resisted emotion norms by directly and openly expressing emotions not commonly associated with their gender. Some women, for example, resisted normative ideas about femininity by describing the anger they felt with respect to criminal justice issues. As in earlier research, these women demonstrated how individuals can "contest, resist, and transform gender by acting differently to what is expected of them according to gender norms" (Jaramillo-Sierra et al., 2017, p. 1828). It was also apparent, though, that most women were unsure of the boundaries for feminine expressions of anger in a criminal justice context. Consequently, many continued to distance themselves from this emotion, seemingly viewing it as inappropriate for their gender and/or as a mock parole board member. 
At the same time, women faced contradictory beliefs about emotion. For women, being emotional can often be viewed negatively (Shields, 2013). However, a failure to express emotion can also be problematic as women may then be viewed as failing to fulfill societal expectations associating femininity with being caring and nurturing (Brescoll, 2016; Shields, 2013). The role of parole decisionmaking also presents a double standard for women, where the job requires women to act one way, but society requires them to act in another. This emotional 'double bind' was most apparent with respect to women's feelings of empathy. While most women described feeling empathy for the offender, they were reticent to admit that these feelings influenced their parole decision. Thus, they used several techniques to distance themselves from their feelings; techniques that allowed them to retain their social identity as caring and compassionate women, whilst also maintaining a level of rationality by denying the importance of empathy to their parole decision.

On the other hand, while many men conformed to gendered feeling rules for fear and anger, they mostly resisted feeling rules for empathy by offering descriptions of this emotion and its importance to their parole decision without reservation. It is not suggested that, by doing so, men have become more emotional. Rather, it appears that within this criminal justice context, men may have a desire to be more emotionally expressive of their empathy. This constitutes a third type of emotion work - that of admission-where an individual may "acknowledge feelings that are present but may not fit with traditional feeling rules" (McQueen, 2017, p. 209). Further, by being expressive of feelings traditionally associated with femininity, men demonstrated more caring forms of masculinity that reject hegemonic ideals of dominance to instead emphasize values of care and relationality (Elliott, 2016).

These findings are significant for several reasons. To begin, this study adds to the existing scholarly literature by providing a valuable contribution to our knowledge of gender differences in public punitiveness, particularly with respect to 'back-end' criminal justice processes that involve the release of prisoners back to the community. For the most part, the existing literature examining public attitudes toward the conditional release of prisoners has relied on surveys or opinion polls to measure public views. While surveys are useful in tapping into public sentiment on an issue at any given time (Berinsky, 2017), to better understand public views of crime and criminal justice we must know more "about the ways in which people process information, and how [their] views relate to previouslyexisting beliefs and attitudes" (Roberts \& Stalans, 2000, p. 7). Thus, by using in-depth qualitative interviews to provide a more nuanced picture of public attitudes toward punishment, this study contributes significantly to the existing research in this area.

Further, while studies have focused on establishing the existence of gender differences in public attitudes toward various criminal justice issues and procedures, that research has rarely engaged with theoretical explanations for why men and women may hold dissimilar views. The use of a theoretical framework for understanding gender differences in public views is essential to uncovering not only 
how men's and women's attitudes differ, but why this may be so. Taking a theoretically informed approach, this study advances our knowledge of the affective dimensions of men's and women's views of parole and demonstrates how emotions can be "boundary breaking" within performances of masculinity and femininity (McQueen, 2017, p. 205).

The findings also highlight, though, that there is no uniform approach for either men or women when it comes to navigating their gender through their presentation of emotion, at least in a criminal justice context. Thus, unlike what might be inferred from Hochschild's (1983) theory, there does not appear to be a clearly demarcated binary division for men or women for the expression or management of emotion. Instead, these findings add weight to the idea that gender (and indeed emotion) is more appropriately viewed as a type of situated social action or performance (West \& Zimmerman, 1987), whereby men and women in modern society can be fluid and changeable in their feelings and behaviors as they navigate the accomplishment of their gender through their display of emotion.

\section{References}

Adriaenssen, A., \& Aertsen, I. (2015). Punitive attitudes: Towards an operationalization to measure individual punitivity in a multidimensional way. European Journal of Criminology, 12(1), 92-112.

Aldrich, N. J., \& Tenenbaum, H. R. (2006). Sadness, anger, and frustration: Gendered patterns in early adolescents' and their parents' emotion talk. Sex Roles, 55(11-12), 775-785.

Alexander, C. S., \& Becker, H. J. (1978). The use of vignettes in survey research. Public Opinion Quarterly, 42(1), 93-104.

Applegate, B. K., Cullen, F. T., \& Fisher, B. S. (2002). Public views toward crime and correctional policies: Is there a gender gap? Journal of Criminal Justice, 30(2), 89-100.

Baker, T., Falco Metcalfe, C., Berenblum, T., Aviv, G., \& Gertz, M. (2015). Examining public preferences for the allocation of resources to rehabilitative versus punitive crime policies. Criminal Justice Policy Review, 26(5), 448-462.

Bandes, S. A., \& Blumenthal, J. A. (2012). Emotion and the Law. Annual Review of Law and Social Science, $8,161-181$.

Berinsky, A. J. (2017). Measuring public opinion with surveys. Annual Review of Political Science, 20, 309329.

Brescoll, V. L. (2016). Leading with their hearts? How gender stereotypes of emotion lead to biased evaluations of female leaders. The Leadership Quarterly, 27(3), 415-428. 
Brody, L. R. (1996). Gender, emotional expression, and parent-child boundaries. In R. D. Kavanough, B. Zimmerberg, \& S. Fein (Eds.) Emotion: Interdisciplinary Perspectives (pp. 139-170). Mahwah, NJ: Lawrence Erlbaum Associates.

Broom, A., Hand, K., \& Tovey, P. (2009). The role of gender, environment and individual biography in shaping qualitative interview data. International Journal of Social Research Methodology, 12(1), 51-65.

Bryant, S. A., \& Spencer, G. A. (2003). University students' attitudes about attributing blame in domestic violence. Journal of Family Violence, 18(6), 369-376.

Butter, R., Hermanns, J., \& Menger, A. (2013). Simultaneous prediction of punitive and rehabilitationoriented attitudes towards probation: An ecological approach. Probation Journal, 60(1), 24-39.

Clark, C. (2007). Misery and company: Sympathy in everyday life. Chicago, Illinois: University of Chicago Press.

Connell, R. W. (1995). Masculinities. Crows Nest, NSW: Allen \& Unwin.

Cops, D., \& Pleysier, S. (2010). 'Doing gender' in fear of crime: The impact of gender identity on reported levels of fear of crime in adolescents and young adults. The British Journal of Criminology, 51(1), 58-74.

Courtright, K. E., Mackey, D. A., \& Packard, S. H. (2005). Empathy among college students and criminal justice majors: Identifying predispositional traits and the role of education. Journal of Criminal Justice Education, 16(1), 125-144.

Cumberland, J., \& Zamble, E. (1992). General and specific measures of attitudes toward early release of criminal offenders. Canadian Journal of Behavioural Science, 24(4), 442.

de Boise, S. (2015). Men, masculinity, music and emotions. Hampshire, UK: Palgrave-Macmillan.

Deutsch, F. M. (2007). Undoing gender. Gender E Society, 21(1), 106-127.

Dey, I. (2004). Grounded theory. In C. Seale, G. Gobo, J.F. Gubrium, \& D. Silverman (Eds.), Qualitative Research Practice (pp. 80-93). London, UK: Sage Publications.

Dodd, S. (2018). The punitive woman? Gender differences in public attitudes toward parole among an Australian sample. International Journal of Offender Therapy and Comparative Criminology, 62 (10), 30063022.

Dolliver, M.J., \& Rocker, D.L. (2018) Addressing a divide in the conceptualization of the gender-crime relationship: A comparative test of General Strain Theory. Deviant Behavior, 39(12), 1152-1565. 
Dowler, K. (2003). Media consumption and public attitudes toward crime and justice: The relationship between fear of crime, punitive attitudes, and perceived police effectiveness. Journal of Criminal Justice and Popular Culture, 10(2), 109-126.

Elliott, K. (2016). Caring masculinities: Theorizing an emerging concept. Men and Masculinities, 19(3), 240-259.

Estrada-Reynolds, V. C., Schweitzer, K. A, Nuñez, N., \& Culhane, S. (2016). Male and female parole decisions: Is paying your dues or saying you're sorry more important? Psychiatry, Psychology and Law, 23(6), 893-907.

Feldman Barrett, L. (2017). How emotions are made: The secret life of the brain. Boston, MA: Houghton Mifflin Harcourt.

Fischer, A. H. (1995). Emotion concepts as a function of gender. In J.A. Russell, J.M. Fernande-Dols, A.S.R. Manstead \& J.C. Wellenkamp (Eds.), Everyday conceptions of emotion: An introduction to the psychology, anthropology, and linguistics of emotion (pp. 457-474). Dordecht, The Netherlands: Springer.

Fitzgerald, R., Bartels, L., Freiberg, A., Cherney, A., \& Buglar, S. (2016). How does the Australian public view parole? Results from a national survey on public attitudes towards parole and reentry. Criminal Law Journal, 40(6), 307-324.

Forseth, U. (2005). Gender matters? Exploring how gender is negotiated in service encounters. Gender, Work E Organization, $12(5), 440-459$.

Frost, W. D., \& Averill, J. R. (1982). Differences between men and women in the everyday experience of anger. In J.R. Averill (Ed.) Anger and Aggression (pp. 281-316). New York, NY: Springer-Verlag.

Galasiński, D. (2004). Men and the Language of Emotions. London, UK: Palgrave Macmillan.

Garland, T. S., Policastro, C., Richards, T. N., \& Miller, K. S. (2017). Blaming the victim: University student attitudes toward bullying. Journal of Aggression, Maltreatment \& Trauma, 26(1), 69-87.

Gault, B. A., \& Sabini, J. (2000). The roles of empathy, anger, and gender in predicting attitudes toward punitive, reparative, and preventative public policies. Cognition \& Emotion, 14(4), 495-520.

Gilchrist, E., Bannister, J., Ditton, J., \& Farrall, S. (1998). Women and the 'fear of crime': Challenging the accepted stereotype. The British Journal of Criminology, 38(2), 283-298.

Gilligan, C. (1982). In a Different Voice. Cambridge: UK: Harvard University Press. 
Goodey, J. (1997). Boys don't cry: Masculinities, fear of crime and fearlessness. The British Journal of Criminology, 37(3), 401-418.

Haghighi, B., \& Lopez, A. (1998). Gender and perception of prisons and prisoners. Journal of Criminal Justice, 26(6), 453-464.

Hanna, E., \& Gough, B. (2016). Emoting infertility online: A qualitative analysis of men's forum posts. Health, 20(4), 363-382.

Hartnagel, T. F., \& Templeton, L. J. (2012). Emotions about crime and attitudes to punishment. Punishment \& Society, 14(4), 452-474.

Hellum, M., \& Oláh, L. S. (2018). 'Doing gender and gender equality' through emotional expressions during a research interview. Views of highly educated Swedish young adults. Journal of Gender Studies. doi: 10.1080/09589236.2018.1441019

Hochschild, A. R. (1979). Emotion work, feeling rules, and social structure. American Journal of Sociology, 85(3), 551-575.

Hochschild, A. R. (1983). The Managed Heart. Berkeley, CA: University of California Press.

Hollander, J. A. (2001). Vulnerability and dangerousness: The construction of gender through conversation about violence. Gender \& Society, 15(1), 83-109.

Hupfeld, J. (2009). Men's and women's theories about the causes of crime: The Influence of severity and type of offence on intentions to punish. In H.-J. Albrecht, T. Serassis, \& H. Kania (Eds.), Images of crime III (pp. 89-104). Berlin, Germany: Duncker \& Humblot.

Hurwitz, J., \& Smithey, S. (1998). Gender differences on crime and punishment. Political Research Quarterly, 51(1), 89-115.

Indermaur, D. \& Hough, M. (2002). Strategies for changing public attitudes to punishment. In J. Roberts and M. Hough (Eds.) Changing attitudes to punishment: Public opinion, crime and justice (pp. 198-214). Cullompton, UK: Willan Publishing.

Jaramillo-Sierra, A. L., Allen, K. R., \& Kaestle, C. E. (2017). Young women's anger in romantic relationships: Gendered rules and power. Journal of Family Issues, 38(13), 1825-1851.

Johnson, D. (2009). Anger about crime and support for punitive criminal justice policies. Punishment $\mathcal{E}$ Society, 11(1), 51-66. 
Jordan, A. (2018). Masculinizing Care? Gender, Ethics of Care, and Fathers' Rights Groups. Men and Masculinities, 1-22. Advance online publication. doi: 10.1177/1097184X18776364

Kelley, J., \& Braithwaite, J. (1990). Public opinion and the death penalty in Australia. Justice Quarterly, 7(3), 529-563.

Kogut, T. (2011). The role of perspective taking and emotions in punishing identified and unidentified wrongdoers. Cognition \& Emotion, 25(8), 1491-1499.

Kopper, B. A., \& Epperson, D. L. (1991). Sex and sex-role comparisons in the expression of anger. Psychology of Women Quarterly, 15(1), 7-14.

Krehbiel, P. J., \& Cropanzano, R. (2000). Procedural justice, outcome favorability and emotion. Social Justice Research, 13(4), 339-360.

Kutateladze, B., \& Crossman, A. M. (2009). An exploratory analysis of gender differences in punitiveness in two countries. International Criminal Justice Review 19(3), 322-343.

Labor, P. D. P., \& Gastardo-Conaco, M. C. C. (2017). The Role of Social Perceptions, Beliefs, and Emotions on Support for Punitive Action toward Drug Dealers and Users. Philippine Journal of Psychology, 50(2), 67-96.

Lacey, N., \& Pickard, H. (2015). To blame or to forgive? Reconciling punishment and forgiveness in criminal justice. Oxford Journal of Legal Studies, 35(4), 665-696.

Lively, K. J. (2000). Reciprocal emotion management: Working together to maintain stratification in private law firms. Work and Occupations, 27(1), 32-63.

Lively, K. J. (2019). Sociological approaches to the study of gender and emotion in late modernity: Culture, structure, \& identity. In R. Patulny et al. (Eds.), Emotions in Late Modernity (pp.69-82). Abingdon, Oxon: Routledge.

Loader, I. (2011). Playing with fire? Democracy and the emotions of crime and punishment. In Karstedt, S., Loader, L., \& Strang, H. (Eds.), Emotions, Crime and Justice (pp. 347-362). Oxford, UK: Hart.

Lutz, C. A. (1996). Engendered Emotion: Gender, Power, and the Rhetoric of Emotional Control. In R. Harré \& W. Gerrod Parrott (Eds.) The Emotions: Social, cultural and biological dimensions (pp. 151-170). London, UK: Sage Publications.

Mackey, D. A., Courtright, K. E., \& Packard, S. H. (2006). Testing the rehabilitative ideal among college students. Criminal Justice Studies, 19(2), 153-170. 
Manderson, L., Bennett, E., \& Andajani-Sutjahjo, S. (2006). The social dynamics of the interview: Age, class, and gender. Qualitative Health Research, 16(10), 1317-1334.

Maruna, S., \& King, A. (2009). Once a criminal, always a criminal? 'Redeemability' and the psychology of punitive public attitudes. European Journal on Criminal Policy and Research, 15(1-2), 7-24.

McQueen, F. (2017). Male emotionality: 'boys don't cry' versus 'it's good to talk'. International Journal for Masculinity Studies, 12(3-4), 205-219.

Messerschmidt, J. W. (2013). Crime as Structured Action: Doing Masculinities, Race, Class, Sexuality, and Crime. Plymouth, UK: Rowman \& Littlefield.

Miller, J., \& Carbone-Lopez, K. (2015). Beyond 'doing gender': Incorporating race, class, place, and life transitions into feminist drug research. Substance Use \& Misuse, 50(6), 693-707.

Miller, J., \& Mullins, C. W. (2006). The status of feminist theories in criminology. In F. T. Cullen, J. P. Wright, \& K. R. Blevins (Eds.), Taking stock: The status of criminological theory (pp. 217-249). London, UK: Transaction Publishers.

Novick, G. (2008). Is there a bias against telephone interviews in qualitative research? Research in Nursing \& Health, 31(4), 391-398.

O'Hear, M., \& Wheelock, D. (2015). Imprisonment Inertia and Public Attitudes Toward Truth in Sentencing. BYU Law Review, 2, 257-306.

Opdenakker, R. (2006). Advantages and disadvantages of four interview techniques in qualitative research. Forum: Qualitative Social Research, 7(4), 1-13.

O’Sullivan, K., Holderness, D., Hong, X. Y., Bright, D., \& Kemp, R. (2017). Public Attitudes in Australia to the Reintegration of ex-Offenders: Testing a Belief in Redeemability (BiR) scale. European Journal on Criminal Policy and Research, 23(3), 409-424.

Petersilia, J. (2003). When prisoners come home: Parole and prisoner reentry. New York, NY: Oxford University Press.

Rabe-Hemp, C. E. (2009). POLICEwomen or policeWOMEN? Doing gender and police work. Feminist Criminology, 4(2), 114-129.

Rade, C. B., Desmarais, S. L., \& Burnett, J. L. (2018). An integrative theoretical model of public support for ex-offender reentry. International Journal of Offender Therapy and Comparative Criminology, 62(8), 2131-2152. 
Roberts, J. V., \& Stalans, L. (2000). Public opinion, crime, and criminal justice. New York, NY: Routledge.

Ross, C. E., \& Van Willigen, M. (1996). Gender, parenthood, and anger. Journal of Marriage and the Family, 58(3), 572-584.

Ryan, M. K., David, B., \& Reynolds, K. J. (2004). Who cares? The effect of gender and context on the self and moral reasoning. Psychology of Women Quarterly, 28(3), 246-255.

Scheibling, C. (2018). "Real Heroes Care": How Dad Bloggers Are Reconstructing Fatherhood and Masculinities. Men and Masculinities, 1-17. Advance online publication. doi: 10.1177/1097184X18816506

Shields, S. A. (2002). Speaking from the heart: Gender and the social meaning of emotion. New York, NY: Cambridge University Press.

Shields, S. A. (2005). The Politics of Emotion in Everyday Life: "Appropriate" Emotion and Claims on Identity. Review of General Psychology, 9(1), 3.

Shields, S. A. (2013). Gender and emotion: What we think we know, what we need to know, and why it matters. Psychology of Women Quarterly, 37(4), 423-435.

Simon, R. W., \& Nath, L. E. (2004). Gender and emotion in the United States: Do men and women differ in self-reports of feelings and expressive behavior? American Journal of Sociology, 109(5), 1137-1176.

Snedker, K. A. (2006). Altruistic and vicarious fear of crime: Fear for others and gendered social roles. Sociological Forum, 21(2), 163-195.

Sorial, S. (2016). Performing anger to signal injustice: The expression of anger in victim impact statements. In C. Abell \& J. Smith (Eds.), The Expression of Emotion: Philosophical, Psychological and Legal Perspectives (pp. 287-379). Cambridge, UK: Cambridge University Press.

Sorial, S. (2019). Emotions and the criminal law: Anger and the defence of provocation. In R. Patulny et al. (Eds.) Emotions in Late Modernity (pp. 129-141). Abingdon, Oxon: Routledge.

Spiranovic, C. A., Roberts, L. D., \& Indermaur, D. (2012). What predicts punitiveness? An examination of predictors of punitive attitudes towards offenders in Australia. Psychiatry, Psychology and Law, 19(2), 249-261.

Sprott, J. B. (1999). Are members of the public tough on crime?: The dimensions of public “punitiveness". Journal of Criminal Justice, 27(5), 467-474.

Sturges, J. E., \& Hanrahan, K. J. (2004). Comparing telephone and face-to-face qualitative interviewing: a research note. Qualitative Research, 4(1), 107-118. 
Sutton, R. M., \& Farrall, S. (2004). Gender, socially desirable responding and the fear of crime: Are women really more anxious about crime? British Journal of Criminology, 45(2), 212-224.

Sutton, R. M., Robinson, B., \& Farrall, S. D. (2011). Gender, fear of crime, and self-presentation: An experimental investigation. Psychology, Crime \& Law, 17(5), 421-433.

Thoits, P. A. (1990). Emotional deviance: Research agendas. In T.D. Kemper (Ed.), Research Agendas in the Sociology of Emotions, (pp. 180-203). Albany, NY: State University of New York Press.

Thornberg, R., \& Knutsen, S. (2011). Teenagers' explanations of bullying. Child \& Youth Care Forum, 40(3), 177-192.

Trier-Bieniek, A. (2012). Framing the telephone interview as a participant-centred tool for qualitative research: A methodological discussion. Qualitative Research, 12(6), 630-644.

Unnever, J. D., \& Cullen, F. T. (2009). Empathetic identification and punitiveness: A middle-range theory of individual differences. Theoretical Criminology, 13(3), 283-312.

Valcore, J. L., \& Pfeffer, R. (2018). Systemic error: Measuring gender in criminological research. Criminal Justice Studies, 31(4), 333-351.

Warr, M. (1984). Fear of victimization: Why are women and the elderly more afraid? Social Science Quarterly, 65(3), 681.

Vîlcică, E. R. (2018). Revisiting parole decision making: Testing for the punitive hypothesis in a large US jurisdiction. International Journal of Offender Therapy and Comparative Criminology, 62(5), 1357-1383.

Vitaglione, G. D., \& Barnett, M. A. (2003). Assessing a new dimension of empathy: Empathic anger as a predictor of helping and punishing desires. Motivation and Emotion, 27(4), 301-325.

West, C., \& Zimmerman, D. H. (1987). Doing gender. Gender \& society, 1(2), 125-151.

Whitehead, J. T., \& Blankenship, M. B. (2000). The gender gap in capital punishment attitudes: An analysis of support and opposition. American Journal of Criminal Justice, 25(1), 1-13.

Williams, C. L., \& Heikes, E. J. (1993). The importance of researcher's gender in the in-depth interview: Evidence from two case studies of male nurses. Gender $\mathcal{E}$ Society, 7(2), 280-291.

Weiner, B., Graham, S., \& Reyna, C. (1997). An attributional examination of retributive versus utilitarian philosophies of punishment. Social Justice Research, 10(4), 431-452. 


\section{Contributor}

Shannon Dodd is a Research Associate in the School of Social Science at the University of Queensland. Shannon has a background in law and criminology and has interests in corrections, public opinion research, and gender.

\section{Footnotes}

1. Adrian Bayley, a convicted violent and sexual offender, raped and murdered Irish woman Jill Meagher in Melbourne, Australia in 2012 while on conditional release on both bail and parole. Despite violating his parole conditions (by being charged with assault in an unrelated incident), his parole had not been revoked. $\bullet$ 